\title{
Exploring production and use of soapstone in Norway: Towards an interdisciplinary approach?
}

\author{
LAURA BUNSE
}

Bunse, L. 2014. Exploring production and use of soapstone in Norway: Towards an interdisciplinary approach? AmSVaria 58, 45-59, Stavanger. ISSN 0332-6306, ISBN 978-82-7760-167-0

In recent years, soapstone research has developed into a multidisciplinary field encompassing a broad range of topics and methodological approaches. Interdisciplinary research now attracts more interest and has contributed significantly to the identification of quarries and understanding of the distribution and use of soapstone. Most collaborative projects have related to certain geographic or thematic areas. As the research on soapstone deposits in Northern Norway illustrates, interdisciplinary work can make important contributions also to other and little explored types of soapstone utilisation. In order to realise the full potential of interdisciplinary research, an expansion of the areas covered and a rethinking of approaches to collaboration and disciplinary compatibility are required. One problem is the use of modern scientific criteria and classification schemes to identify and interpret stone sources, as such methods do not necessarily capture all the aspects of the material that were crucial to past users and production.

Laura Bunse, PhD fellow in archaeology, Tromsø University Museum, NO-9037 TROMSØ, NORWAY.

Phone (+ 47) 77645061. E-mail: laura.bunse@uit.no

Keywords: soapstone, deposit, quarry, production, utilisation, provenance, sourcing, distribution, interdisciplinary, typology, classification, compatibility

\section{Introduction}

Soapstone has been quarried and used in Norway for various purposes from the Stone Age onwards. In the Stone Age, it was used to make net sinkers, small clubs and animal figurines, while in the Bronze Age, it became an important raw material for casting moulds. The first soapstone vessels were produced in the transition from the late Bronze Age to the Pre-Roman Period but disappear from the record in the first half of the Roman Period. The production of soapstone vessels restarted in the late Iron Age and continued throughout the Medieval Period. Soapstone also became an important material for ashlars and decorative stone in churches and other medieval town buildings. Even today, there is a demand for it, especially in the fireplace industry and for restoration of medieval churches (Storemyr \& Heldal 2002).

The numerous soapstone quarries in Norway are of both geological and archaeological interest. Geological surveys have made an important contribution to the identification and mapping of soapstone quarries and also to the historical changes in types of production. Whilst archaeological research initially focused on typological studies of soapstone artefacts, later approaches have developed to include quarry investigations and studies of the social aspects of soapstone production. An interdisciplinary approach is required to address the most important contemporary research issues, including the chronological framework of production, distribution and trade in soapstone products and the people involved in quarrying.

In recent years, the need for, and potential benefits of, an interdisciplinary approach to ancient stone production have been demonstrated by several national and international studies, many of which are very relevant to soapstone research. Moreover, methods in soapstone research have improved significantly over the last decade and there are several ongoing interdisciplinary collaborations. Nevertheless, these new approaches seem predominantly concerned with research into certain types of production, in particular the production of vessels 
and building stone. Recent studies of soapstone quarries in Northern Norway, carried out as part of the author's ongoing $\mathrm{PhD}$ project, suggest that an interdisciplinary approach can be equally beneficial to other fields of soapstone research. These studies have also demonstrated the need for re-examination of geological and archaeological data and methods in order to facilitate better communication and cross-disciplinary understanding between researchers from different disciplines and thus to tap the full potential of interdisciplinary research.

In this article, I start with a review of soapstone research, including studies on other stone sources of importance to soapstone production. This is followed by a brief overview of what is known about the Northern Norwegian quarries, in order to illustrate the need to expand interdisciplinary collaboration to other geographic and thematic areas of soapstone use. Finally, the compatibility of the methods used in the various disciplines will be discussed with an emphasis on potential problems relating to the application of scientific categories to archaeological material.

\section{Soapstone research - a multi-faceted field} Contemporary soapstone research is a wide field, encompassing several disciplines and a number of different thematic and methodological sub-fields such as sourcing, studies of provenance, artefact studies of e.g. vessels or fishing tools, as well as investigations into different types of production such as building stones and bakestones. Geology and archaeology are important contributory disciplines, but so too are fields such as history, stonemasonry, and architecture. Among the most important research topics are the identification and documentation of quarries, including their chronology, and the distribution and consumption of the products. In recent years, interdisciplinary research has attracted more interest and has contributed significantly to advances in our understanding of these topics by driving improvements in methodology, particularly for research into provenance and sourcing. At present, however, most interdisciplinary research concentrates on certain geographic or thematic areas. This section reviews current soapstone research and the potential for interdisciplinary approaches to work on the production and use of soapstone.

\section{Identification and documentation}

Early archaeological soapstone research in the late $19^{\text {th }}$ and early $20^{\text {th }}$ century focused on typological artefact studies, and so the identification of soapstone quarries and traces from previous production remained primarily a geological issue, at least until the first archaeological investigations of quarries in the 1960s. Since the pioneering work of Amund Helland (1893), who carried out the first survey of soapstone deposits, the Geological Survey of Norway (NGU) and other geological surveys have been of vital importance in identifying and mapping soapstone quarries. In parallel, work to document and understand the chronology of soapstone production has become a major part of geological research (cf. Storemyr \& Heldal 2002). The mineral resource database is probably the most complete source of information on soapstone deposits in Norway and includes maps, photos, geological data and descriptions of previous production. The NGU literature database is also a useful resource and includes a broad range of geological and archaeological publications on soapstone.

As the coordinating body for national and international interdisciplinary projects such as Millstone on Norwegian millstone quarries (Selsing 2014) and QuarryScapes on ancient building stone quarries in the Near East (Abu-Jaber et al. 2009), the NGU has broad experience in quarry research and documentation. The QuarryScapes guide to ancient stone quarry landscapes (Heldal \& Bloxam 2008) is of particular relevance to soapstone research, but also to quarry research in general by providing useful guidance on how to identify, document and analyse ancient quarries. It also includes definitions of terms, which are especially useful for interdisciplinary projects, and fact sheets for describing various quarry features. In addition, the Millstone project, which drew on several disciplines and various forms of expertise, successfully demonstrated the potential of interdisciplinary research as an approach to identifying and documenting quarry landscapes.

These projects have also allowed the NGU to contribute significantly to investigations into the use of soapstone as a building material for ashlars and decorative stone in Norwegian medieval stone churches. The NGU department for Natural Construction Materials works to identify the original sources of the stone used in the numerous medieval stone churches, e.g. the Nidaros Cathedral in Trondheim, in order to find suitable materials for restoration (Storemyr 1995, 2000, Grenne \& Heldal 2001, 2002). In the course of this work, the NGU has identified a number of previously unknown quarries and has documented quarrying techniques, periods of production, transportation routes and distribution. Naturally, soapstone is primarily used as building material in areas rich in soapstone deposits and so investigations have been concentrated on material and sources pertaining to Bergen in Western Norway (Heldal 
\& Jansen 2000), Trondheim in Central Norway (Heldal \& Storemyr 1997, Storemyr \& Heldal 2002) as well as Helgeland in the southern part of Northern Norway (Lindahl 2012). As detailed below, recent archaeological excavations, provenance studies and information from historic sources and church architecture have all contributed to the understanding of building stone quarries (cf. Storemyr et al. 2010).

\section{Chronology and dating}

The date of production in building stone quarries can partly be reconstructed from historical written sources, but knowledge about the absolute date of production for other soapstone artefacts is often dependent on radiocarbon dating of samples from archaeological excavations. As mentioned above, archaeological soapstone research has to a large extent concentrated on typological artefact studies, especially of soapstone vessels, including research into the relative chronology of the production of such items. Classifications of vessels are based on the identification of two main periods of production. The first probably started at the end of the Bronze Age and reached its climax in the Pre-Roman Iron Age, gradually tailing off in the Roman Period (Rygh 1885, Shetelig 1912, Petersen 1934, Møllerop 1959, Pilø 1990), whereas the second began in the late Iron Age and continued throughout the Medieval Period (Rygh 1885, Shetelig 1912, Grieg 1933, Petersen 1951, Lossius 1977, Resi 1979). Vessels from the first period of production are bucket-shaped, whereas vessels from the late Iron Age and Medieval Period are bowl- or troughshaped. Recent studies of medieval finds also detected differences between vessels from the late Iron Age and those of the Medieval Period (Vangstad 2003). Several studies of fishing tools also provided a relative chronology of soapstone net sinkers (Helberg 1993, Olsen 2004). Soapstone vessels were in use for several hundred years, however, and small changes in size and shape may be hard to identify from quarry evidence. More precise dating techniques are therefore needed to establish chronologies for production in the quarries.

Spoil heaps with potential for further excavation were uncovered through early test pits and trenches in three quarries in southeast Norway (Petersen 1922, Skjølsvold 1961:48 and 1961:48 and 52, Østerås 2002:18), but it was not until Arne Skjølsvold's (1961) pioneering investigations of Viking Period soapstone quarries that serious attention was paid to the sites of production. Skjølsvold also conducted the first proper archaeological excavation of a soapstone quarry at Kvikne, Central Norway. Radiocarbon dating indicated that it was used for production in the Pre-Roman Period and to date this is the oldest documented soapstone quarry in Norway (Skjølsvold 1969).

The results of Skjølsvold's investigations were promising, but it was not until the late 1990s that follow-up excavations were carried out. Investigations at Klungen (Berg 1998, 1999) and Bakkaunet (Østerås 2008) in Trondheim revealed extensive traces from the production of building stone. Unfortunately, no datable material was found, but as mentioned above, by combining archaeological results, geological survey data and historical sources it was possible to link the quarries to the period during which the Nidaros Cathedral was built (Storemyr et al. 2010). Excavations of the vessel quarries at Slipesteinsberget to the north of Trondheim (Østerås 2002) and Remman in the Helgeland area (Berglund 1999) provided radiocarbon dates, which indicated that there was production at both quarries in the Medieval Period. During the process to assess the merits of re-opening the Kvikne quarry to act as a source for restoration work on the Nidaros Cathedral a second excavation in a different area of the deposit documented small rectangular extractions that had been completely covered by soil, leaving no visible traces of production on the surface. Due to their size and shape it has been suggested that these extractions were used for the production of Bronze Age casting moulds, but this hypothesis conflicts somewhat with the radiocarbon dating, which suggests that the extractions belong to the Pre-Roman Iron Age (Østerås 2004).

Excavations of soapstone quarries have also been conducted in the US (Parkman 1983, Turnbaugh et al. 1984), on Shetland (Forster \& Turner 2009) and Greenland (Pasda 2011). Although not all of them provided samples for radiocarbon dating, they successfully demonstrated that stratigraphy of the spoil heaps can reveal different periods of production.

These examples show that excavations can provide a much more precise chronology of quarrying activity and also provide detailed information on the differences and relationships between quarries within a certain area. Because traces of previous production left on the rock face are often removed by later quarrying activity, excavation is often the only source of evidence for earlier production periods. As well as shedding light on chronology and stratigraphy, excavations also make it possible to calculate average volumes of production based on the amount of debris and the number of extractions on the rock face (Skjølsvold 1961, 1969, Berglund 1999, Østerås 2002, 2004).

Until recently, excavations have tended to be conducted independently from geological surveys although 
the results were sometimes incorporated into subsequent interdisciplinary discussions. However, the recent investigations of millstone quarries in Western Norway conducted by Irene Baug (2015) have demonstrated the merits of expanding the scope of interdisciplinary research to encompass field work. Involving geologists in the selection of areas for investigation helped in obtaining more representative areas for archaeological surveys. As well as considering the quarries' location relative to transport routes and farms or estates, an important goal was to find different types of quarries with respect to products, size, technology, stone quality and mineral composition. In her investigation of a green schist quarry for decorative stone and bakestones at Øye in Trondheim, Nina Lundberg (2007) applied a similar approach. In close collaboration with geologists, areas for excavation and the collection of samples were selected and tool marks, quarrying techniques and extractions documented and interpreted. Collaborative fieldwork also greatly increases the chances of detecting quarries and traces from previous production; besides, it is often crucial to the collection of representative stone samples for geochemical analyses and provenance studies, as these must represent the variety of mineral composition within the deposit.

\section{Distribution and trade}

Several archaeological studies have discussed trade and distribution based on comparative artefact studies and archaeological context. There has been a special emphasis on trade in soapstone vessels in the Viking Period. Ground breaking in this respect was the classification of soapstone material from the Viking Age town of Hedeby (Resi 1979), which documented similarities to Norwegian finds. Geochemical analyses undertaken in connection with artefact studies by Alfsen and Christie (1979) confirmed that the soapstone vessels found in Hedeby had been imported from Norway. Ole Risbøl (1994) used finds from settlements and burials in Norway, Denmark and Sweden as the basis for an investigation into the distribution and exchange of soapstone vessels in southern Scandinavia during the Late Iron Age. He argued that the numerous examples of soapstone vessels in high-status male burials is indicative of the deceased's decisive role in soapstone trade. In his study of soapstone production and trade in the Agder region in Southern Norway during the Viking Age, Torbjørn Preus Schou (2007) analysed archaeological material and the distribution of soapstone quarries in order to identify routes of exchange and central distribution points. He concluded that the locations of transport routes and transfer sites were partly determined by topographic and geographic factors, particularly access to waterways. In a later study of the parties involved in the Agder soapstone trade (Schou 2015), Schou introduced sociological structuration theory and the concepts of longue durée and duality of structure as previously applied to Viking Age trade by Søren Sindbæk (2005). Discussing the interactions of the various parties in the soapstone trade networks in relation to production, regional transportation to transfer sites and subsequent distribution to consumers, he now suggests that transport routes were primarily determined by the people involved, through repeated and routinised use. Amanda Kate Forster's research on soapstone trade in the North Atlantic Region during the Viking and Early Medieval Period (Forster 2004, 2009) should also be mentioned in this section. With a particular emphasis on soapstone artefacts on Shetland, she concludes that the low number of Norwegian finds does not support previous assumptions about soapstone export from Norway to Shetland.

These examples demonstrate that although a thorough study of the archaeological context may constitute a solid framework for the understanding of trading networks and distribution, geochemical analyses will often be required to achieve more precise results. In recent years, methods for sourcing soapstone have improved and Norwegian research has contributed significantly to this advancement. The internal variations in mineral composition in deposits pose a challenge for research into soapstone provenance. Mineral composition can be a useful indicator, but it does not provide conclusive evidence and must be complemented by geochemical analyses (cf. Storemyr \& Heldal 2002:367-368, Jansen et al. 2003:582). Cluster analysis of trace elements in soapstone finds from the Viking Age town of Hedeby, northern Germany (Alfsen \& Christie 1979) and rare earth element (REE) distribution patterns in Dorset culture soapstone artefacts in Labrador, Canada (Allen et al. 1984) have proved useful in distinguishing among possible sources, but a multi-method approach, combining several types of geochemical analysis, seems to provide more conclusive results.

In order to estimate the provenance of soapstone in medieval buildings in Bergen, Jansen et al. (2003) combined REE patterns with trace element signatures (MTE) and isotopic analysis, which had not previously been applied to soapstone. In areas where there are only a few possible sources, using MTE obtained through X-ray fluorescence (XRF) may be sufficient for distinguishing between them, especially in combination with analysis of REE patterns through inductively coupled plasma 
mass spectrometry (ICP-MS). However, the method presented by Jansen et al. (2003) has proved much better at differentiating soapstone deposits with similar mineral composition. An alternative approach, used successfully by Clelland et al. (2009, cf. Bray 1994) in connection with sourcing of soapstone on Shetland, uses magnetic data to complement MTE and REE analyses.

The natural science based provenance study of Bergen soapstone conducted by Jansen et al. (2003) provided important insights into the distribution and use of soapstone in Western Norway in the Medieval Period. At the same time, the authors emphasised the significance of interdisciplinary research and that careful attention should be paid also to the archaeological context. Research on medieval architecture in Bergen conducted prior to the provenance study has also been vital to understanding the broader context relating to the use of soapstone as a building material in this area (cf. Ekroll 1997, Lidén \& Mageröy 1980, 1983, 1990, Helle 1982, Lidén 2000).

At present, interdisciplinary approaches to soapstone research are most advanced in provenance studies, but scientific results cannot by themselves provide insight into the choices, decisions and appraisals of the raw material made by people in the past (cf. Knapp 2000). As illustrated above, to address these issues requires a broader understanding of the particular socio-cultural context. Though complex and fragmented, detailed studies of the archaeological record can provide access to this context and, in tandem with natural science approaches, allow for more comprehensive and nuanced understandings.

\section{Production and consumption}

Recent studies of soapstone evidence from excavated settlement sites have provided important insight into the daily use of soapstone and shifted the focus from quarries to other sites of production. Egil Brodshaug and Brit Solli (2006, cf. Brodshaug 2005) have analysed the soapstone vessel material from the medieval longhouse at Borg (Borg III) in Lofoten, Northern Norway. The nature and distribution of the various vessel types gave indications of their function as cooking pots and enabled the researchers to reconstruct the spatial arrangement of the different areas within the house. Analyses of organic crust on the vessel sherds provided evidence that they had been used as cooking pots for meals consisting of fish, milk, vegetables and meat, possibly cooked together as a stew. Irene Baug's (2011) study of soapstone material from the Viking Age town of Kaupang, southeast Norway, showed numerous examples of small objects re-worked from vessel sherds or produced from raw soapstone in the town. There is also evidence for the domestic production of small soapstone tools from Viking Age settlements on Shetland (Forster 2009) and at the Viking Age chieftain's farm at Borg (Borg I) in Lofoten (Johansen et al. 2003).

These finds show that soapstone production was not restricted to quarries or nearby related processing places because traces of production were also found at settlement sites. They also suggest that research into production, especially production of easy-to-produce items for everyday use such as net sinkers or loom weights, should include settlement sites. An interesting approach to this issue has been proposed by human geographer Stefan Nilsson (2002:91-96) in his study of soapstone artefacts from the excavated medieval farmstead at Skramle, Sweden. Discussing whether they represent local products manufactured on site or items that came to the farmstead through trade, he established a set of criteria for distinguishing between them, which may have wider relevance. The most significant traces of domestic production include the presence of unformed or partially manufactured soapstone pieces, soapstone debris, the presence of tools suitable for working soapstone, and related tool marks on soapstone objects. The absence of some of the indicators does not necessarily mean that an item was produced off site, but their presence is a positive indication of production at a settlement site.

As illustrated by research on millstones (cf. Selsing 2014), ethnographic studies and knowledge of stonemasonry can provide interesting perspectives on the social and practical organisation of production and may also raise awareness of the cultural preferences of past users and the emic qualities associated with the raw material. Edward Breck Parkman (1983), for example, described how the Kumeyaay Native American people of the southwestern US and northwest Mexico used soapstone for various tools and cooking pots, as warming stone in curing and puberty rites and, in powdered form, as a medicine. Not only did the artefacts have a technical function, they also had an "ideotechnical" function linked to the specific features of the raw material, which apparently contributed to their practical and symbolic meanings.

Without necessarily providing any directly applicable analogies, ethnographic research is also important to fuel and inform discussions of the gender, age and social identity of both users and producers, e.g. stonecutters. Stonecutters are usually thought of as adult men, even if this is not stated explicitly. The building stones and soapstone vessels produced in Norwegian soapstone quarries are huge and heavy items and the assumption that stonecutters were men presumably derives from the assumption that quarrying involved heavy manual labour. If not 
in any way decisive, ethnographic evidence may help a critical scrutinising of such assumption. A recent study from Greenland (Pasda 2011), for example, demonstrated that quarrying, especially of smaller items, also involved women and children. John C. Erwin (2010) arrived at a similar conclusion in his re-interpretation of some finds from the Dorset quarry at Fleur de Lys, Newfoundland. Based on the apparently non-professional manufacture of some extremely small soapstone pots and the fact that their extractions in the quarry are at ground level, he suggested that they represent the work of children. In a Norwegian context, this may be particularly relevant to the manufacture of small artefacts that do not require as much precision as vessels or building stones, e.g. net sinkers or loom weights.

As mentioned above, inclusion of the expertise of present stonemasons, as done in the Millstone project, can provide valuable insight into production processes and the factors that may have determined how stone was quarried and used. An interdisciplinary study of millstone quarries in Saltdal, Northern Norway identified traces of technical development as an adaptation to geological and morphological conditions (Grenne et al. 2014). The stonemason Eva Stavsøien from the Nidaros Restoration Workshop conducted experiments on quarrying and manufacturing soapstone vessels as part of her bachelor's thesis on restoration and technical building preservation (Stavsøien 2012) and also participated in several interdisciplinary discussions and field surveys (cf. Østerås 2002). A main challenge in terms of reconstructing soapstone production processes, however, is the fact that traces from the working of soapstone artefacts were often removed as part of the finishing and hence the only evidence of tool marks is often on rock faces in the quarries (Stavsøien 2012). Reconstruction of the production process is further complicated by the fact that a single tool can create several different tool marks and vice versa. Choice of tools and technique would also have been influenced by factors such as stone quality, availability of tools, working height etc. Stavsøien emphasised, however, that there are some general principles which apply to working soapstone regardless of the tools used or the product made and that they are due to the distinctive features of the raw material.

Her conclusion is supported by the fact that techniques noted in Norwegian soapstone quarries, e.g. removal of material around the items to be quarried and removal of blanks by splitting with a wedge, have also been document elsewhere e.g. Switzerland, Shetland, Greenland or Newfoundland. Further, the notion that the qualities and characteristics of the material strongly influence how it was processed and used is corroborated by finds of similar products in very different geographical and chronological contexts. In particular, the production of soapstone vessels has been documented in many prehistoric or early historic soapstone quarries around the world (cf. Rütimeyer 1924, Parkman 1983, Erwin 2010, Pasda 2011).

To conclude this brief review of soapstone research, one important trend noticed is the increased emphasis on interdisciplinary approaches. This trend seems to continue to develop and is facilitated by several research projects and initiatives that actively integrate different kinds of expertise. At the same time, it should be noted that most interdisciplinary research in Norway focuses on the production, provenance and distribution of building stone and soapstone vessels, and is mostly confined to the areas of Bergen, Trondheim and Helgeland. As the discussion in this section hopefully has demonstrated, there are great potential gains to be achieved by expanding interdisciplinary research into other thematic and methodological areas, such as surveys and data collection in the field, dating and assessment of quarries, and analysis of different types of production, such as the making of small artefacts and domestic, non-professional production. In the next section, this is illustrated by considering the example of soapstone use in Northern Norway.

\section{A wider perspective: Soapstone use in Northern Norway}

Recent investigations of soapstone deposits in Northern Norway, conducted as part of the author's ongoing $\mathrm{PhD}$ project, documented traces of a little noticed use of soapstone that is quite different from the vessel and building stone quarries in other parts of the country. The lack of chronological and sociocultural evidence suggests that an interdisciplinary approach may be required to understand this use. At the same time, the evidence for different types of use calls into question the "normalised" templates and categories used in Norwegian soapstone research and demonstrates the need to adopt wider and more flexible perspectives, both in terms of research topics and classification of the material.

\section{Small extractions and their uses}

The area of investigation is confined to the administrative district of the Tromsø University Museum and includes the northern part of Nordland County, as well as the northernmost counties of Troms and Finnmark. The NGU's mineral stone database (MSD) and the national database for cultural heritage $(C H D)$ suggest that, within this area, there are about 10 to 15 sites of 


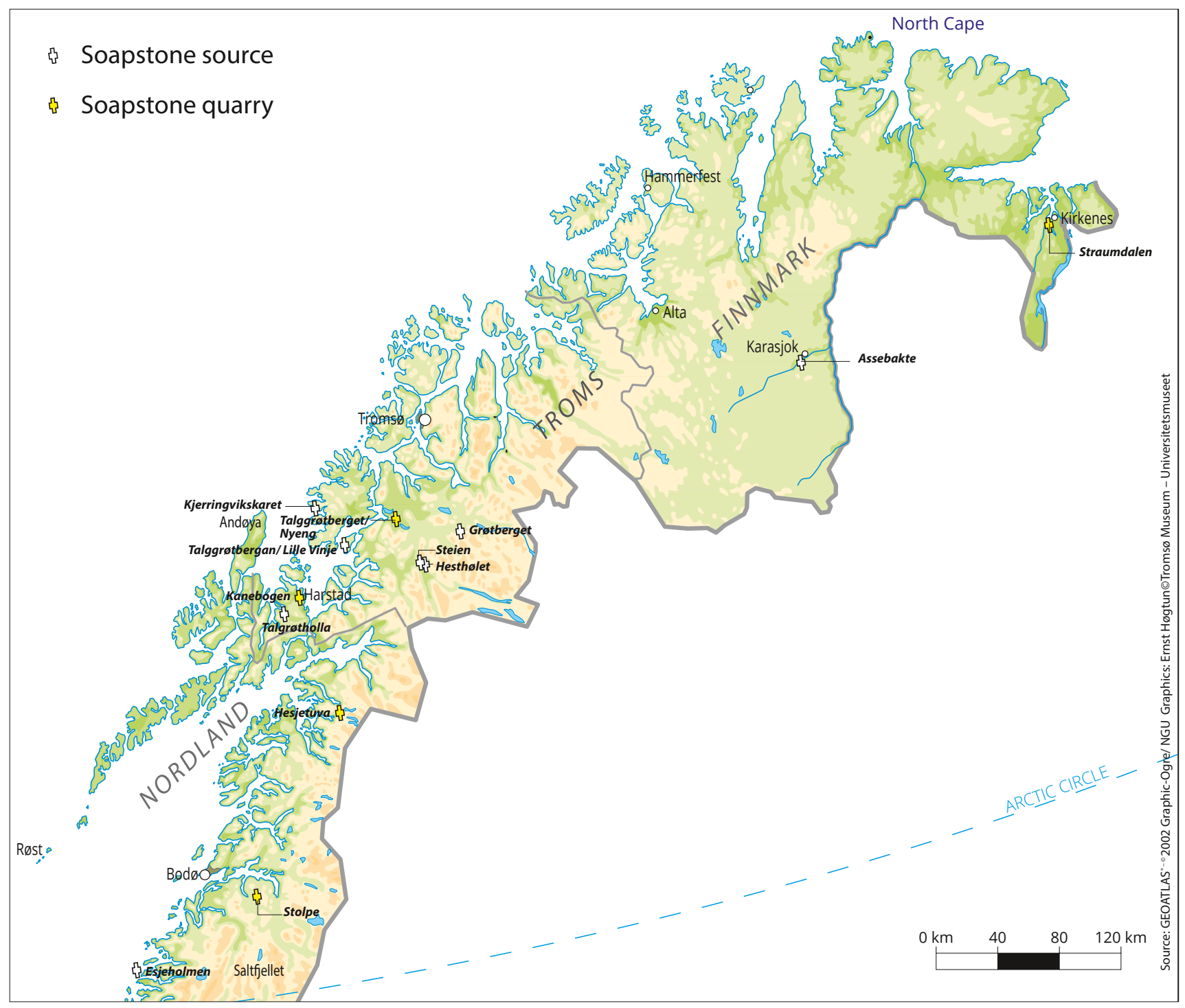

Fig. I. Investigated soapstone deposits in Northern Norway. Illustration: Ernst Høgtun, Tromsø University Museum.

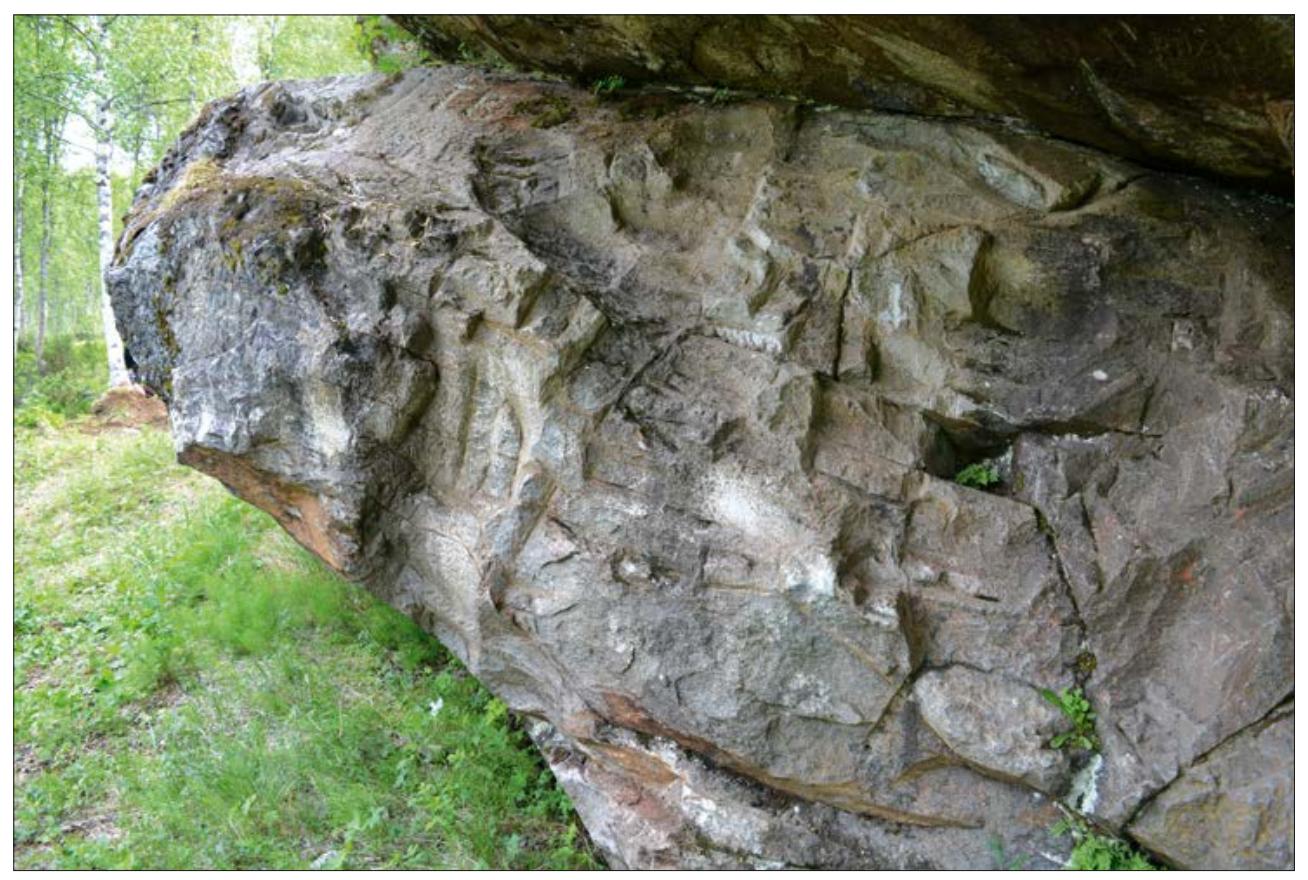

Fig. 2. Small extractions in a soapstone quarry at Talggrøtberget. Photograph: Laura Bunse. 


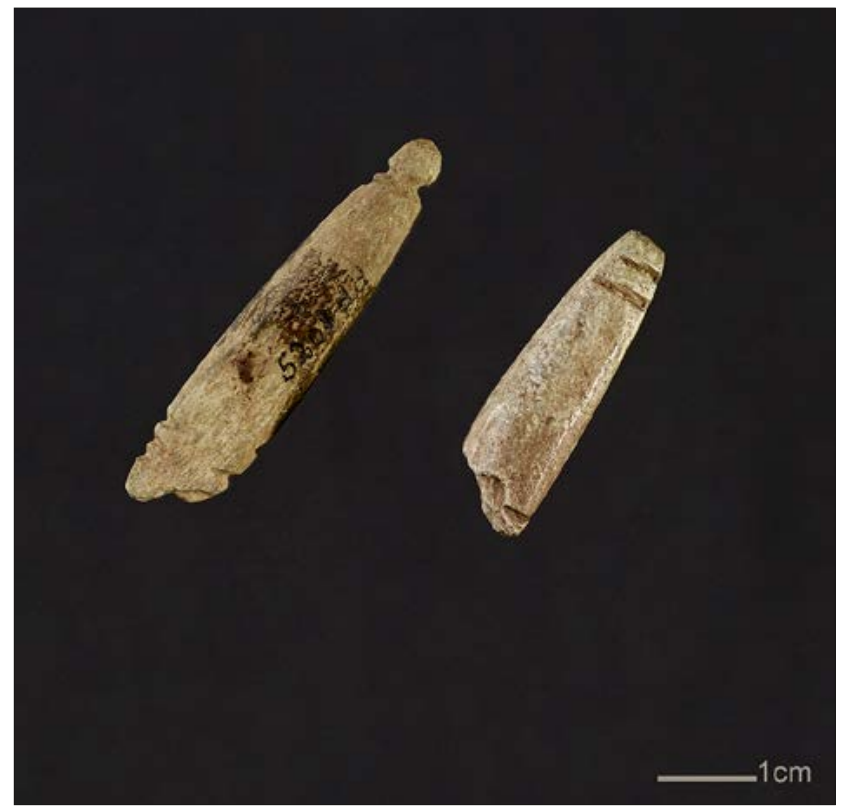

Fig. 3. Fishing jigs from Noatun, Pasvik Valley, Finnmark. Photograph: Mari Karlstad, Tromsø University Museum. soapstone deposits with traces of possible early use, though the exact number of utilised deposits is difficult to estimate. Although the MSD lists all known soapstone deposits in Norway, the CHD only contains deposits that show traces of prehistoric or historic use. The majority of sites mentioned in the $C H D$ are listed in the $M S D$, but the $C H D$ also includes a few sites that are not recorded in the $M S D$. These are primarily sites that cannot be classified geologically as soapstone, but which were quarried and used for the same purposes as soapstone or have a vernacular name related to soapstone. This in itself exemplifies a possible tension or incongruence between science-based classification and emic categories based on local skills and knowledge.

In 2013 and 2014, archaeological investigations were conducted at 11 deposits (Fig. 1) and extractionsfrom previous production were documented at Stolpe and Hesjetuva in Nordland County, Kanebogen and Talggrøtberget in Troms County and Straumdalen in Finnmark County

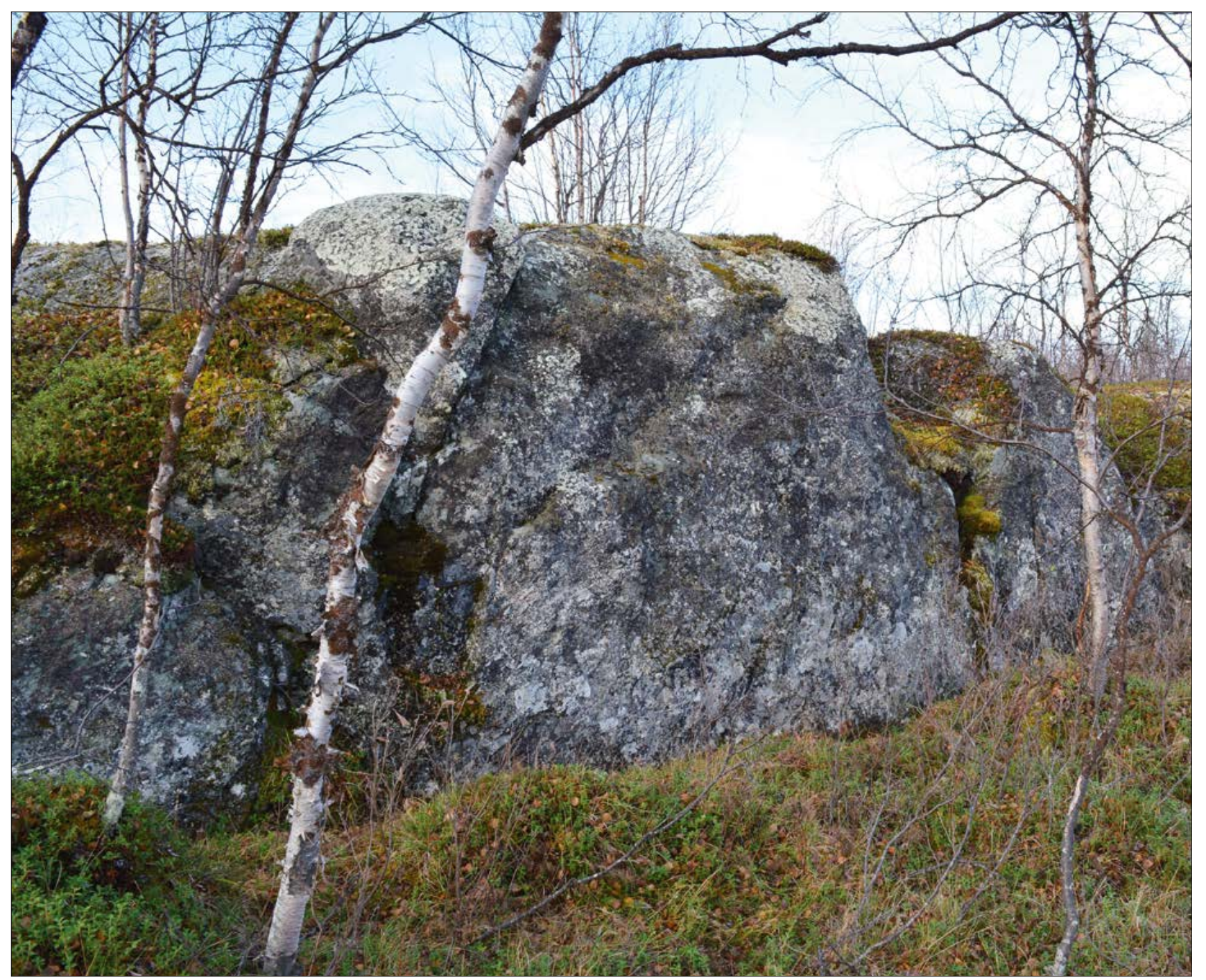

Fig. 4. The Assebakte soapstone deposit in Finnmark. Photograph: Laura Bunse. 
(Bunse 2013a,b,c,d,e, 2014a,b, 2015). With exception of Stolpe, which also displays traces from the production of vessels, all the quarries are characterised by small, mainly rectangular extractions - sometimes with rounded corners - and a few disc-shaped extractions. The size of the rectangular extractions varied from $5-20 \mathrm{~cm}$ in width and $15-30 \mathrm{~cm}$ in length, whilst the average diameter of the disc-shaped extractions measured approximately 15 $\mathrm{cm}$ (Fig. 2). It is difficult to relate the shape of the extractions to a particular type of artefact and it seems likely that they represent the production of blanks for various small tools such as net sinkers, loom weights, oil lamps, spindle whorls and casting moulds.

Archaeological finds from excavated settlement sites indicate that soapstone was also used for even smaller items, such as the small fishing jigs from the Late Stone Age site of Noatun in Pasvik Valley, Finnmark (Fig. 3). Both Noatun and the Early Metal Period sites of Makkholla and Mestersanden on the island of Kjelmøy yielded a few soapstone tempered ceramics and small soapstone pieces with cutting marks and polished surfaces. Because these finds were restricted to areas with access to soapstone, it has been assumed that they were made from local raw materials (Olsen 1984:13, 35-38, 63, Skandfer 2003:117, 131). The finds suggest that soapstone deposits were exploited in a way that leaves hardly any visible traces on the rock face, so it is possible that the number of exploited sites is higher than was previously assumed.

Some deposits might have been more than a source of raw material. The name of the Assebakte deposit in Finnmark derives from the Sámi word Ássebákti, which means "soapstone" or "soft rock that is easy to carve" (Nielsen \& Nesheim 1962:5). The deposit consists of a long knoll, approximately $5 \mathrm{~m}$ high and $15 \mathrm{~m}$ long, which is clearly silhouetted against the slightly undulating landscape (Fig. 4). The name Assebakte is also applied to the surrounding area, which is strewn with scattered boulders; as is common with Sámi place names, Assebakte seems to refer to prominent features in the landscape. Sámi place names give information about, for example, the topography of the area, weather specific to the area or its reindeer pasture and often function as "orientation guides". At Assebakte, a track passing close to the deposit and several nearby fireplaces give the impression that the site was a natural place for a rest. The path and fireplaces seem to have been used recently for reindeer herding, but may also have been used further back in time. In the vicinity, there is also an investigated settlement site dated to the Viking Age and Early Medieval Period, though without finds of any soapstone artefacts (Simonsen 1979). The Stabben deposit in Troms appears to have had a similar function

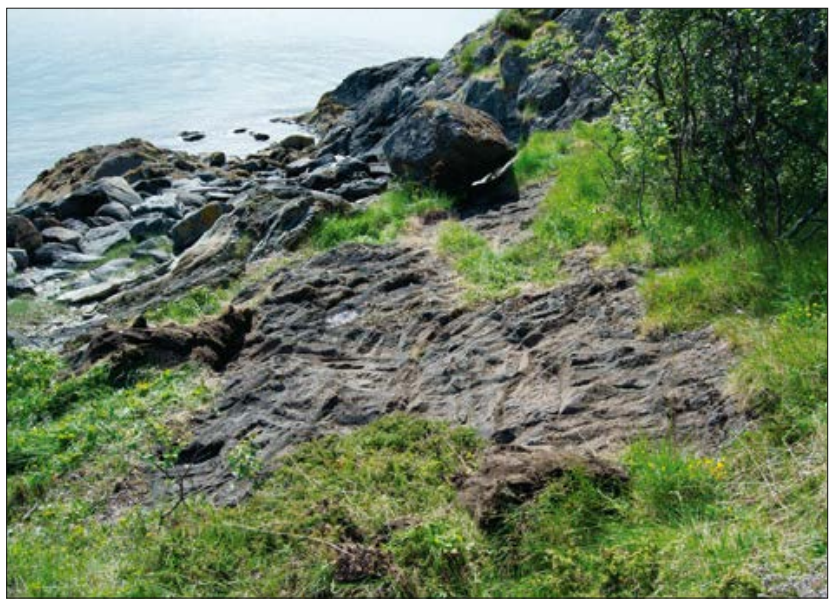

Fig. 5. Small rectangular extractions at Kanebogen. Photograph: Laura Bunse.

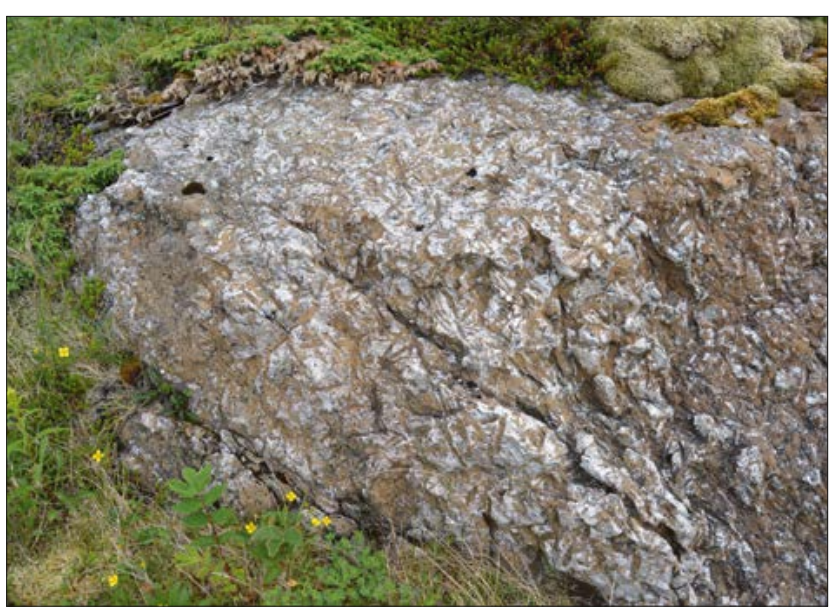

Fig. 6. Esjeholmen in Nordland. Photograph: Laura Bunse.

(Lindahl \& Nilsson 2002); owing to its characteristic, prominent shape, it is known as a landmark and a sieidi, a sacred place in the landscape worshipped in traditional Sámi religion as gateway to the spirit world.

The area also contains deposits that cannot be classified as soapstone, but which were exploited and used for the same purposes and/or were considered to be similar to or share some of the qualities as soapstone. The extractions at Kanebogen in Troms are of the same size and display the same technique as the other quarries investigated (Fig. 5), although much of the source is not actually soapstone (Wickler et al. in press). The Esjeholmen deposit in Nordland consists of enstatite with jackstraw olivine texture (Karlsen et al. 1999). Archaeological investigations in 2013 found no traces of production. However, the name probably derives from the Norwegian vernacular name for soapstone esje or hesje. In this case, it truly refers to the talc content and soft texture of the Esjeholmen outcrop, which is similar to soapstone (Fig. 6). A similar situation has been observed in Värmland, Sweden. Several small soapstone 
deposits were found in the area, but in places that lack true soapstone, other workable rocks were used as a substitute (Nilsson 2002:88, 91).

\section{Implications for interdisciplinary research}

The dearth of chronological and sociocultural evidence raises several theoretical and methodological problems related to the identification of exploited sites, the different types of use and their dating, the distribution of products and the people involved in production and use. Important issues for future investigations are which factors determined production in Northern Norway and why mainly small artefacts were produced. Was it due to natural conditions like stone quality, occurrence and accessibility, or due to sociocultural aspects like different traditions for soapstone use, or maybe both? Which qualities and features were appreciated and demanded by the users? Did composition, quality, texture and colour of the rock play a role? What types of products were made locally and which came to the area by trade - and were local products distributed more widely? It seems likely that a cooperative approach, which goes beyond the scope of current interdisciplinary soapstone research will be required to address these issues.

To get a more comprehensive picture of soapstone use through time, it is necessary to consider sites of occasional or small-scale production of expeditious items as well as large-scale, professional, semi-industrial production of vessels and building stone. Here, etymology can be a useful supplement to geological surveys, archaeological investigations, artefact studies and historical sources. Although etymology has yet to make a fundamental contribution to Norwegian soapstone research, the study of place names has contributed significantly to the identification of exact quarry locations in Britain (Moorhouse 2005, Brooke-Freeman 2009). In the context of the Northern Norwegian sites, it would be especially interesting to examine the relationship between Norwegian and Sámi words for soapstone and the use of vernacular names for soapstone. Were sites like Esjeholmen actually believed to be soapstone or does the term esje refer to rock features that occur in other types of rock as well?

As the example of the Sámi word sieidi illustrates, findings from the Northern Norwegian deposits reinforce the importance of ethnography, social anthropology and cultural studies when it comes to identifying types of use and the parties involved. To date, little attention has been paid to ethnicity and possible variations in soapstone quarrying and uses of soapstone in Norwegian soapstone research, but they are issues of relevance both in northern and more southern areas of Norway.
In connection with provenance, the gradual broadening of geographic research areas and increasing use of comparisons with neighbouring countries seems a reasonable long-term strategy. The archaeological material from Northern Norway displays evidence of cultural contacts and exchange networks with southern Scandinavia, northern Sweden, Finland and Russia, so research on the provenance of soapstone from these regions will provide important comparative evidence on sourcing of soapstone artefacts from Northern Norway. To my knowledge there have so far been no provenance studies on soapstone finds from northern Sweden, Finland or Russia; however results from geochemical analyses of soapstone deposits in Finland (Wiik 1953, Vesasalo 1965) and an ongoing PhD project by Andreas Nilsson (in press) at Lund University, Sweden on the provenance of soapstone casting moulds from the Bronze Age seem promising sources of comparisons with future results from Northern Norway.

Stonemasonry expertise may be useful in determining the working properties of the raw material, although the substantial differences between past and present techniques and tasks are an important consideration. Contemporary stonemasons usually work with soapstone that has already been quarried, however there are basic principles for working soapstone, determined by the features of the raw material and so the stonemasonry perspective may be relevant to all types of soapstone production.

The potential benefits of interdisciplinary research on the Northern Norwegian soapstone deposits are obvious; however, the Kanebogen and Esjeholmen sites in particular also highlight the problems associated with applying scientific categories to archaeological or cultural historical material, for example the method of classification can predetermine both the content and interpretation of evidence. In the field of archaeology, this issue has frequently been discussed in connection with typology and artefact classifications and it seems an even more crucial issue in interdisciplinary research. The greater the number of disciplines involved in a project, the more difficult it is to create a common categorical template or classification system. The need to reach agreement on terminology and find a common framework for identification and documentation of quarries remains one of the key challenges for interdisciplinary research.

\section{Compatibility and the problem of classification}

Classification systems are essential for structuring the research material into manageable categories for 
interpretation, and also for communication between scientists. However, an awareness of the formation and development of classification systems and how they are used by scientists is necessary to understand the classification process and different interpretations of the material. The debate about typology and classification of artefacts in archaeology highlights several of the problems that can occur when applying scientific categories to archaeological material. Special emphasis has been on the question of whether scientific classification systems are able to grasp and identify categories and aspects of the material that mattered to its past users (Hill \& Evans 1972, Adams \& Adams 1991, Skandfer 2003). The main issues of the typology debate have also been subject to the general discussion on the relation between folk taxonomy and scientific classification systems, with special emphasis on the reality of plant and animal species (cf. Berlin 1973, Atran 1998, Holman 2002, Begossi et al. 2008, Khalidi 2013). A central issue in this debate is whether scientific categories are real and universally valid or constructed by scientists; a question that also may be relevant to applications of scientific categories to archaeological materials such as stone sources. The following section examines the problem of classification in soapstone research and its implications for interdisciplinary collaborations in the light of the broader debate on classification in archaeology.

\section{Scientific categories - real or constructed?}

Typology was developed at the end of the $19^{\text {th }}$ century and is one of the main principles of archaeology. By organising artefacts into types based on physical characteristics, it helps to manage the large amount of archaeological material and provides an overview of artefact development and chronological order. However, typology can still be criticised for being based on subjective, constructed classifications which have little relevance to the find context, technology or sociocultural background of the find. The development of typology has been strongly influenced by evolutionary theory, which is reflected in type classifications evolving from the primitive, ineffective far back in time to the advanced, beautiful and effective. The definitions of types are often based on the scientist's personal perspective and more closely related to aesthetic criteria than representativeness; they must therefore be judged in historical context (Skandfer 2003:57-62).

Typology was for a long time believed to reflect natural divisions of the material, but since the 1960s and 1970s, a discussion has started on the reality of types and the arbitrary of typologies. Central issues have been whether it is possible to establish "best type divisions" and on which features the types should be based (Hill \& Evans 1972). Instead of regarding types as a result of chronological development, it was argued that they represent adaptation to changing natural conditions and that typology should to a larger degree be based on functional and technical aspects. However, the function and technology of artefacts cannot always be reconstructed and physical features have remained the main criterion for classification (cf. Adams \& Adams 1991, Skandfer 2003:63-64).

Inspired by hermeneutics and the philosophy of the construction of meaning, discussion also has included questions on whether the different types represent real, $a$ priori, intrinsically meaningful categories, which would have been relevant in the past, or whether they represent categories constructed by scientists and are based on personal preferences. Artefacts of the same type usually share distinctive features and it has been argued that these attributes were chosen and created by the producers in the past and should therefore be considered 'real'. Differences emphasised by scientific classification may well have been recognised in the past, but their distinctions would not necessarily correspond to scientific classifications (Skandfer 2003:59). According to Adams \& Adams (1991), types and classifications often represent a combination of natural and constructed features; they argued that artefacts and their users have a relationship of interdependence influenced by both natural and cultural factors (Adams \& Adams 1991).

Typology enables the researcher to classify and arrange investigated material clearly, providing a general overview and a manageable amount of data. Classification thus seems essential to interdisciplinary research, and the use of a combination of systems or the integration of different classification systems may be required to make the material understandable to scholars from all the disciplines involved. However, as emphasised by Whittaker et al. (1998), the classification process itself poses a potential source of error. In order to provide a foundation for communication and interpretation, one has to make sure that scientists using the same typology agree on definitions of types and organise the material in similar ways and thus are able to use the classification consistently and effectively. Without quality control and clear type definitions, subjectivity in the classification process may increase and can result in different perceptions and interpretations of the material. Classification thus is not only a theoretical, but also a practical issue that requires agreement on and a clear definition of types. This seems particularly important for interdisciplinary collaboration. 


\section{Compatibility and definitions}

Classification is also always based on a selection of features; in other words, on choices. This means that only some of the attributes of the material are taken into consideration, while those that are not considered significant or do not fit into the predetermined categories are excluded or ignored. The application of scientific categories to archaeological material will therefore always involve choices that influence research content and interpretation to a larger or lesser degree.

In the context of soapstone research, geological classifications of stone sources have usually played a decisive role in the choice of sites for investigation. Scientific techniques such as geochemical analyses have been used to interpret the features, quality and workability of raw materials. Unlike archaeological artefact types, geological classifications are based primarily on scientific evidence and are rarely challenged by emic, folk-based knowledge or their cultural schemes of categorising the world. Though geological classification is coherent and based on true evidence, it may still be the case that the resulting categories ignore aspects of the material that were relevant to past producers and users of soapstone. This is illustrated by, for example, evidence that stone sources that cannot geologically be termed soapstone were exploited for the same purposes or associated with the same features as soapstone. From an archaeological perspective, the situation is very different. Our ambition must be to understand the features and qualities that past users sought and appreciated in their conception and use of the raw material. Whilst mineral composition and other geological features would naturally have influenced past production and use, they are not sufficient or relevant for detecting and incorporating all aspects that may have played a role in past peoples' perceptions of the raw material. From an interdisciplinary perspective, it may be claimed that archaeology is torn between, on the one hand, the domains of science and objective fact, which provide manageable, easily comparable data, and, on the other hand, the cultural historical domain, in which the aim is to understand how people engaged with and approached the world and its resources. Although there is no easy or definitive solution to this schism, and compromises are inevitable, an awareness of disciplinary differences in terms of theory, methods and goals would, in my opinion, prove helpful and facilitate collaboration and hopefully broaden researchers' perspectives on stone source identification and interpretation.

\section{Concluding remarks}

Contemporary soapstone research is a wide field, encompassing a number of disciplines, research topics and methodological approaches. Interdisciplinary research, which has been central to the broadening of research perspectives and improvements in methods, now attracts more interest and has contributed significantly to the understanding of soapstone production and use through time, especially through studies of provenance and distribution. However, collaborations still tend to concentrate on certain geographic or thematic areas. As recent studies of soapstone deposits in Northern Norway have illustrated, interdisciplinary research can make an equally important contribution to other areas of soapstone research, but this will require an expansion of its current scope and a reconsideration of ways of collaborating. Accommodating the application of scientific classifications to archaeological material poses a significant challenge, as to some extent such classifications dictate the content and interpretation of evidence and may not be capable of capturing all the aspects of a raw material that mattered to past users. An awareness of theoretical and methodological differences between the disciplines is necessary in order to tap the full potential of interdisciplinary collaboration, since it allows a broadening of research perspectives to also include variations and less frequent types of use, which can significantly contribute to a more thorough and complex understanding of past soapstone production and use.

\section{Acknowledgements}

I wish to acknowledge geologist Gurli Meyer from the Geological Survey of Norway, stonemason Eva Stavsøien from the Nidaros Restoration Workshop and the members of the soapstone research network for interesting discussions and for sharing their knowledge with me. I also thank my supervisors Roger Jørgensen and Bjørnar Olsen for helpful comments and guidance. Finally, I am grateful to the referees for their constructive feedback and useful suggestions.

\section{References}

Abu-Jaber, N., Bloxam, E.G., Degryse, P., Heldal, T. (eds.) 2009. QuarryScapes: ancient stone quarry landscapes in the Eastern Mediterranean. Geological Survey of Norway, Special Publication 12.

Adams, W.Y., Adams, E.W. 1991. Archaeological typology and practical reality: a dialectical approach to artifact classification and sorting. Cambridge University Press, Cambridge.

Alfsen, B.E. \& Christie, O.H.J. 1979. Massenspektrometische Analysen von Specksteinfunden aus Haithabu und wikingerzeitlichen Specksteinbrüchen in Skandinavien. In Resi, H. G. (ed.) Die Specksteinfunde aus Haithabu. Berichte über die Ausgrabungen in Haithabu 14, pp. 170-183. Schleswig-Holsteinisches Landesmuseum für Vor- und Frühgeschichte, Neumünster. 
Allen, R., Hamroush, H., Nagle, C., Fitzhugh W. 1984. Use of rare earth element analysis to study the utilization and procurement of soapstone along the Labrador Coast. Archaeological Chemistry III, 3-18.

Atran, S. 1998. Folk biology and the anthropology of science: Cognitive universals and cultural particulars. Behavioral and Brain Sciences 21, 547-609.

Baug, I. 2011. Soapstone Finds. In Skre, D. (ed.) Things from the Town. Artefacts and Inhabitants in Viking Age Kaupang, pp. 311-337. Kaupang Excavation Project, Publication Series Vol. 3. Norske Oldfunn XXIV, Aarhus.

Baug, I. 2015. Quarrying in Western Norway. An Archaeological Study of Production and Distribution in the Viking Age and Middle Ages. Archaeopress Archaeology, Oxford.

Begossi, A., Clauzet, M., Figueiredo, J.L., Garuana, L., Lima, R.V., Lopes, P.F., Ramires, M., Silva, A.L., Silvano, R.A.M. 2008. Are Biological Species and Higher-Ranking Categories Real? Fish Folk Taxonomy on Brazil's Atlantic Forest Coast and in the Amazon. Current Anthropology 49 (2), 291-306.

Berg, A. 1998. Rapport fra arkeologisk undersøkelse ved Klungen, Melhus kommune, Sør-Trøndelag, 7-25 juni 1998. Report T22398A-E. Department of Archaeology, Norwegian University of Science and Technology.

Berg, A. 1999. Ny aktivitet i gammelt steinbrudd. Spor 2, 20-22.

Berglund, B. 1999. Middelaldersk klebersteinsindustri på Helgelandskysten. Ottar 225, 13-24.

Berlin, B. 1973. Folk Systematics in Relation to Biological Classification and Nomenclature. Annual Review of Ecology and Systematics 4, 259-271.

Bray, I. S. J. 1994. Geochemical methods for provenance studies of steatite. Unpublished PhD thesis, University of Glasgow.

Brodshaug, E. 2005. Det anonyme dagliglivet: klebersteinsmaterialet fra de arkeologiske utgravningene av Borg III, Vestvågøy i Lofoten. Unpublished Master thesis in archaeology, University of Tromsø.

Brodshaug, E., Solli, B. 2006. Kleber, mat og rom på Borg i middelalderen. Viking, 289-306.

Brooke-Freeman, E. 2009. Locating Shetland Steatite using Place Name Evidence. In Forster, A. K. \& Turner, V. E. (eds.). Kleber: Shetland's Oldest Industry, pp. 18-26. Shetland Amenity Trust, Lerwick.

Bunse, L. 2013a. Klebersteinsforekomsten på Hesjetuva. Årbok for Tysfjord 31, 10-11.

Bunse, L. 2013b. Rapport fra arkeologisk befaring. Hesjetuva, Tysfjord kommune, gbnr.28/1 og 4, Nordland fylke. Unpublished report, Tromsø University Museum.

Bunse, L. 2013c. Rapport fra arkeologisk befaring av klebersteinforekomster. Unpublished report, Tromsø University Museum.

Bunse, L. 2013d. Rapport fra arkeologisk befaring av et klebersteinsbrudd i Langfjorden, Sør-Varanger kommune, Finnmarkfylke. Unpublished report, Tromsø University Museum.

Bunse, L. 2013e. Rapport fra arkeologisk befaring. Stolpe, Bodø kommune, gbnr. 224/2, Nordland fylke. Unpublished report, Tromsø University Museum.

Bunse, L. 2014a. Rapport fra mindre arkeologisk utgraving $i$ et klebersteinsbrudd i Langfiorden, Sør-Varanger kommune,
Finnmark. Unpublished report, Tromsø University Museum.

Bunse, L. 2014b. Rapport fra arkeologisk undersøkelse $i$ klebersteinsbruddet Talggrøtberget, Sørreisa kommune, Troms fylke, sommeren 2014. Unpublished report, Troms $\varnothing$ University Museum.

Bunse, L. 2015. Rapport fra arkeologisk utgraving. Stolpe, gbnr. 224/2, Nordland fylke. Unpublished report, Tromsø University Museum.

Clelland, S.-J., Batt, C. M., Stern, B., Jones, R. 2009. Scientific Analysis of Steatite: recent results. Forster, A.K. \& Turner, V.E. (eds.). Kleber: Shetland's Oldest Industry, pp. 106-117. Shetland Amenity Trust, Lerwick.

Ekroll, Ø. 1997. Med kleber og kalk. Norsk steinbygging $i$ mellomalderen. Det Norske Samlaget, Oslo.

Erwin, J.C. 2010. Dorset Paleoeskimo Quarrying Techniques and the Production of Little Pots at Fleur de Lys, Newfoundland. In Brewer-LaPorta, M., Burke, A., Field, D. (eds.). Ancient Mines and Quarries. A Trans-Atlantic Perspective, pp. 56-66. Oxam Books, Oxam.

Forster, A.K. 2004. Shetland and the Trade of Steatite Goods in the North Atlantic Region during the Viking Age and Early Medieval Period. Unpublished PhD thesis, Department of Archaeological Science, University of Bradford.

Forster, A.K. 2009. Viking and Norse Steatite Use in Shetland. In Forster, A.K. \& Turner, V.E. (eds.). Kleber: Shetland's Oldest Industry, pp. 58-69. Shetland Amenity Trust, Lerwick.

Forster, A.K. \& Turner, V.E. 2009. Kleber: Shetland's oldest industry. Shetland soapstone since prehistory. Shetland Amenity Trust, Lerwick.

Grenne, T. \& Heldal, T. 2001. Fremtidige driftsmuligheter og kulturminnevern i Bubakk klebersteinsforekomst, Kvikne. Report 2001.110. Geological Survey of Norway, Trondheim.

Grenne, T. \& Heldal, T. 2002. Driftsmuligheter og kulturminnevern i Bubakk klebersteinsforekomst, Kvikne. Report 2002.113. Geological Survey of Norway, Trondheim.

Grenne, T., Meyer, G.B., Heldal, T., Jansen, Ø.J., Løland, T. 2014. Technological development in millstone quarrying through the Middle Ages: the Salten quarries, Northern Norway. In Selsing, L. (ed.) Seen through a millstone, pp. 227-244. AmS-Skrifter 24. Museum of Archaeology, University of Stavanger.

Grieg, S. 1933. Middelalderske byfund fra Bergen og Oslo. Det Norske Videnskaps-Akademi, Oslo.

Helberg, B.H. 1993. Fiskeriteknologi som uttrykk for sosial tilhørighet: en studie av nordnorsk fiske i perioden 400-1700 e.Kr. Unpublished Magister thesis in archaeology, University of Tromsø.

Heldal, T. \& Bloxam, E.G. 2008. QuarryScapes guide to ancient stone quarry landscapes: documentation, interpretation and statement of significance. Work Package 9, Deliverable No.11. INCO-CT-2005-015416Project QuarryScapes.

Heldal, T. \& Jansen, Ø.J. 2000. Steinbyen Bergen: fortellingen om brostein, bygg og brudd. Nord4, Bergen.

Heldal, T. \& Storemyr, P. 1997. Geologisk undersøkelse og arkeologisk registrering av de middelalderske bruddene ved Øye, Klungen og Huseby i Sør-Trøndelag. Report 97.149. Geological Survey of Norway, Trondheim. 
Helland, A. 1893. Tagskifere, heller og vekstene. Universitetsforlaget, Oslo.

Helle, K. 1982. Bergen bys historie 1. Universitetsforlaget, Bergen/Oslo/Tromsø.

Hill, J.N., Evans, R.K. 1972. A modell for classification and typology. In Clarke, D.L. (ed.). Models in Archaeology, pp. 231-273. Methuen, London.

Holman, E.W. 2002. The Relation between Folk and Scientific Classifications of Plants and Animals. Journal of Classification 19, 131-159.

Jansen, Ø.J., Heldal, T., Pedersen, R.B., Ronen, Y., Kaland, S.H.H. 2003. Provenance of soapstone in medieval buildings in the Bergen region, Western Norway. Asmosia VII. Proceedings of the 7th International Conference of Association for the Study of Marble and Other Stones in Antiquity, Thassos 15-20 september, 2003. Bulletin De Correspondance Hellénique, Supplément 51, 581-595.

Johansen, O.S., Kristiansen, K., Stamsø Munch, G. 2003. Soapstone artefacts and whetstones. In Stamsø Munch, G., Johansen, O.S., Roesdahl, E. (eds.). Borg in Lofoten. A chieftain's farm in north Norway, pp. 141-158. Arkeologisk Skriftserie I, Lofotr - Vikingmuseet på Borg.

Karlsen, T.A., Gautneb, H., Lund, B. 1999. Status-report on talc-prospecting in Helgeland, Northern Norway. Report 99.068. Geological Survey of Norway, Trondheim.

Khalidi, M.A. 2013. Natural Categories and Human Kinds: Classification in the Natural and Social Sciences. Cambrigde University Press, Cambrigde.

Knapp, A. B. 2000. Archaeology, Science-Based Archaeology and the Mediterranean Bronze Age Metals Trade. European Journal of Archaeology 3 (1), 31-56.

Lidén, H.-E. 2000. Mariakirken i Bergen. Mangschou, Bergen.

Lidén, H.-E., Mageröy, E.M. 1980. Norges kirker, Bergen I. Gyldendal Norsk forlag, Oslo.

Lidén, H.-E., Mageröy, E.M. 1983. Norges kirker, Bergen II. Gyldendal Norsk forlag, Oslo.

Lidén, H.-E., Mageröy, E.M. 1990. Norges kirker, Bergen III. Gyldendal Norsk forlag, Oslo.

Lindahl, I., Nilsson, L.P. 2002. En vurdering av klebersteinspotensialet $i$ Troms. Report 2002.077. The Geological Survey of Norway, Trondheim.

Lindahl, I. 2012. Bygningsstein i Nordland. En oversikt over bygningsstein $i$ Nordland, om bruken og om de forskjellige geologiske steinprovinsene. Geological Survey of Norway, Trondheim.

Lossius, S.M. 1977. Kleberkarmaterialet fra Borgund, Sunnmøre. Arkeologiske avhandlinger fra Historisk Museum. Bergen University.

Lundberg, N. 2007. Øye - en arkeologisk undersøkelse av et klorittskiferbrudd. Unpublished Master thesis in archaeology, Norwegian University of Science and Technology, Trondheim.

Moorhouse, S. 2005. The quarrying of building stone and stone artefacts in medieval Yorkshire: a multi-disciplinary approach. In Klápste, J. \& Sommer, P. (eds.). Arts and crafts in medieval rural environment. Ruralia $I V$, 22nd-29th September 2005, Szentendre E Dobogóko, Hungary, 295-319.

Møllerop, O. 1959. Kleberkar fra keltertid. Årbok Stavanger Museum, 21-40.

Nielsen, K., Nesheim, A. 1962. Lappisk ordbok: grunnet på dialektene i Polmak, Karasjok og Kautokeino. Universitetsforlaget, Oslo.
Nilsson, A. (in press). Soapstone moulds in southern Scandinavia during the Late Bronze Age - origin - use distribution. Conference Paper: Craft and People. Agents of Skilled Labour in the Archaeological Record. British Museum, London.

Nilsson, S. 2002. Soapstone artefacts at Skramle - handicraft or trade? In Andersson, S., Svensson, E. (eds.). Skramle the true story of a deserted medieval farmstead, pp. 86-97. Lund Medieval Studies in Archaeology 27.

Olsen, B. 1984. Stabilitet og endring. Produksjon og samfunn i Varanger 800 f.Kr.-1700 e.Kr. Unpublished Master thesis in archaeology, University of Tromsø.

Olsen, O.M. 2004. Medieval Fishing Tackle from Bergen. In Øye, I. (ed.). Medieval Fishing Tackle from Bergen and Borgund. The Bryggen Papers, Main Series 5, pp. 11-106. Fagbokforlaget, Bergen.

Parkman, E.B. 1983. Soapstone for the Cosmos. Archaeological Discoveries in the Cuyamaca Mountains. Journal of California and Great Basin Anthropology 5, 140 -155 .

Pasda, C. 2011. Karibujäger in Grönland. Die Ergebnisse der archäologischen Untersuchungen von 2005-2009 im hinteren Nuuk-Fjord. Internationale Archäologie. Verlag Marie Leidorf GmbH, Rahden/Westfalen.

Petersen, J. 1922. Et besøk ved klebersteinsbruddet paa Folvelsæter. Naturen 46, 236-239.

Petersen, J. 1934. De eldste norske kleberstenskar fra jernalderen. Finska Fornminnesföreningens Tidskrift XL, 43-48.

Petersen, J. 1951. Vikingetidens redskaper. Skrifter utgitt av Det Norske Vitenskaps-Akademi i Oslo. HistoriskFilosofisk klasse 4.

Pilø, L. 1990. Early Soapstone Vessels in Norway from the Late Bronze Age to the Early Roman Iron Age. Acta Archaeologica 60, 87-100.

Resi, H.G. 1979. Die Specksteinfunde aus Haithabu. Berichte über die Ausgrabungen in Haithabu 14. Schleswig-Holsteinisches Landesmuseum für Vor- und Frühgeschichte, Neumünster.

Risbøl, O. 1994. Socialøkonomiske aspekter ved vikingetidens klæberstenshandel i Sydskandinavien. Lag 5, 115-161.

Rütimeyer, L. 1924. Ur-Ethnographie der Schweiz. Ihre Relikte bis zur Gegenwart mit prähistorischen und ethnographischen Parallelen. Schriften der schweizerischen Gesellschaft für Volkskunde. Bd. 16. Helbing \& Lichtenhahn, Basel.

Rygh O. [1885]. Norske Oldsager. Tapir Forlag 1999, Trondheim.

Schou, T.P. 2007. Handel, produksjon og kommunikasjon - en unders $ø$ kelse av klebersteinsvirksomheten i Aust-Agders vikingtid med fokus på Fjære og Landvik. Unpublished Master thesis in Archaeology, University of Bergen.

Schou, T.P. 2015. The soapstone vessel production and trade of Agder and its actors. In Hansen, G., Ashby, S.P., Baug, I. (eds.). Everyday Products in the Middle Ages. Crafts, Consumption and the Individual in Northern Europe $c$. AD 800-1600, pp. 204-228. Oxbow Books, Oxford and Philadelphia.

Selsing, L. (ed.) 2014. Seen through a millstone. AmS-Skrifter 24. Museum of Archaeology, University of Stavanger.

Shetelig, H. 1912. Kar av klebersten fra jernalderen. Oldtiden, tidsskrift for norsk forhistorie II, 49-73. 
Simonsen, P. 1979. Juntavadda og Assebakte: to utgravinger på Finnmarksvidda. Acta Borealia B. Humaniora 17. Universitetsforlaget, Tromsø/Oslo/Bergen.

Sindbæk, S. 2005. Ruter og rutinisering - Vikingetidens fiernhandel i Nordeuropa. Multivers, København.

Skandfer, M. 2003. Tidlig, nordlig kamkeramikk: typologi, kronologi, kultur. Unpublished Doctoral thesis in archaeology, University of Tromsø.

Skjølsvold, A. 1961. Klebersteinsindustrien i vikingetiden. Universitetsforlaget, Oslo - Bergen.

Skjølsvold, A. 1969. Et keltertids klebersteinsbrudd fra Kvikne. Viking XXXIII, 201-238.

Stavsøien, E. 2012. Fra fast fjell til gryte. Å arbeide med kleberstein, - hva skjuler seg i prosessen? Unpublished Bachelor thesis, BYG819T, project no. 13-2012. HiST, Sør-Trøndelag University College.

Storemyr, P. 1995. Gjenopptakelse av middelalderens steinbrudd? Muligheter for fremtidige steinleveranser til restaureringen av Nidarosdomen. Report 9501. Geological Survey of Norway, Trondheim.

Storemyr, P. 2000. Attempt at Reopening Klungen Medieval Soapstone Quarry for Modern Use at Nidaros Cathedral. 98/034198 Project 59. The Restoration Workshop of Nidaros Cathedral, Trondheim.

Storemyr, P. \& Heldal, T. 2002. Soapstone production through Norwegian history: geology, properties, quarrying, and use. In Herrmann, J. J., Herz, N. \& Newman, R. (eds.). Interdisciplinary Studies on Ancient Stone, pp. 359-369. Asmosia 5, London.

Storemyr, P., Lundberg, N., Østerås, B., Heldal, T. 2010. Arkeologien til Nidarosdomens middelaldersteinbrudd. In Bjørlykke, K., Ekroll, Ø., Syrstad Gran, B. (eds.). Nidarosdomen - ny forskning på gammel kirke. Nidaros Domkirkes Restaureringsarbeiders forlag, Trondheim.
Turnbaugh, W.A., Turnbaugh, S.P., Keifer, T.H. 1984. Characterization of selected soapstone sources in southern New England. In Ericson, J.E. \& Purdy, B.A. (eds.). Prehistoric quarries and lithic production, pp. 129-138. University Press, Cambridge, London, New York, New Rochelle, Melbourne, Sydney.

Vangstad, H. 2003. Kleberkarene fra Bryggen i Bergen. En arkeologisk analyse av kleberkarene funnet på Bryggen i Bergen fra middelalder og etterreformatorisk tid. Unpublished Master thesis in archaeology, University of Bergen.

Vesasalo, A. 1965. Talc Schists and Soapstone Occurences of Finland. Bulletin de la Commission Géologique de Finlande 216.

Whittaker, J.C., Caulkins, D., Kamp, K.A. 1998. Evaluating Consistency in Typology and Classification. Journal of Archaeological Method and Theory 5 (2), 129-164.

Wickler, S., Lindahl, I., Nilsson, L.P. (in press). Soapstone in northern Norway: Archaeological and geological evidence, quarry survey results, and future research potential.

Wiik, H.B. 1953. Composition and Origin of Soapstone. Bulletin de la Commission Géologique de Finlande 165.

Østerås, B. 2002. Slipsteinsberget i Sparbu. Kva undersøkingar av eit klebersteinsbrot kan fortelje om gamle steinhoggartradisjonar. Unpublished Master thesis in archaeology, Norwegian University of Science and Technology, Trondheim.

Østerås, B. 2004. Rapport fra arkeologisk utgraving. Kvikneskogen sameige, Sandbekkdalen, Tynset. Hedmark Fylkeskommune.

Østerås, B. 2008. Rapport arkeologisk utgraving. Report 035702. NTNU University Museum, Trondheim. 